胆囊壁と肝臓・肝門部右側との連続性に関する解剖学的研究

香川医科大学第 1 外科
脇 正 志 田 中 聰
浜松医科大学第 1 外科
吉 田 雅 行
藤枝市立志太総合病院外科
錦 野 光 浩 寺 門 道 之

\title{
A STUDY ON OF THE ANATOMICAL RELATIONSHIP OF THE GALLBLADDER WALL TO THE HEPATIC PARENCHYMA AND THE RIGHT PART OF THE PORTA HEPATIS
}

\section{Masashi WAKI*, Satoshi TANAKA*, Masayuki YOSHIDA** Mitsuhiro NISHIKINO*** and Michiyuki TERAKADO***}

${ }^{*}$ First Department of Surgery, Kagawa University School of Medicine **First Department of Surgery, Hamamatsu University School of Medicine ***Department of Surgery, Shida General Hospital, Fujieda

胆囊と肝実質および肝門部間膜組織との解剖学的つながりについて，新生児を含む剖検肝 34 例をも ちいて肉眼および光䫓下の観察を行った。肝床部では胆震壁最外層のリンパ管と肝内の小莱間組織と の間につながりが認められること，胆虽頸部の壁は右肝動脈，右肝管，門脈右枝をつつむ肝門部右側 の間膜組織と境界なく移行し，リンパ管を主とするつながりが認められることを指摘した。墏膜下組 織に浸潤の及ぶ胆霊癌の外科治療では, これらの進展経路に対して十分の注意をはららべきことを述 ベた.

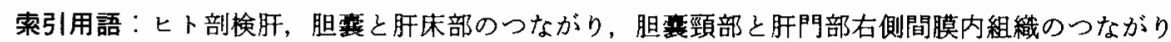

はじめに

現在, 胆囊癌の手術に関して種々さまざまの術式が 提言され，進行癌に対しては，膵十二指腸切除に加え て拡大肝右葉切除を行らべきであるとの意見もある。 しかし，現実にはこのような拡大手術は適応が可能な 症例にかぎりがあり，比較的早期の進行癌では多くの より縮小した術式が提言されている(1).

一方, 比較的早期の胆囊癌に対する問題点として, 第 1 に，術前診断が今日でも困難な場合が少なくない こと ${ }^{4}$, 第 2 に, 胆道癌取扱い規約 5 では stage I の症例 でも, ss 癌では単純な胆摘術のみではその半数以上が 再発を免れないことがあきらかになっている6)、第 2

\footnotetext{
$<1988$ 年12月 14 日受理 $>$ 別刷請求先：脇 正志 厂761 香川県高松市三条町 $260-2$
}

点の理由として，切除標本の検討から， ss 癌ではすで に多くの症例で肝十二指腸間膜から肝内の間膜組織一 とつながる非連程的な間質への浸潤や，予想外以遠方 ヘのリンパ節転移がしばしば認められること, 肝床部 から肝実質内への非連続的進展む進展経路として重要 であることなどが主張されてきだフ

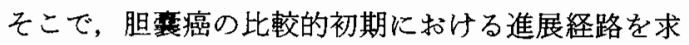
めるため, 剖検材料を用いて, 胆襄付着部から肝門に 至る立体的構造に対する解剖学的考察を試みた。この 結果は, 比較的早期の胆囊癌に対する手術術式の選択 に寄与するるのと考学られる。

\section{対象および方法}

成人 29 ，小児 2 , 新生児 3 の34体の剖検肝を用いた。 小児, 新生児の 5 体と成人の 20 体では胆囊と肝臓との 間の構造的関係を調べるため, 胆囊の長軸方向に, 胆 
図 1 胆高と肝, 肝門の位置関係の模式図. 3 本の線 は割面方向を示す。

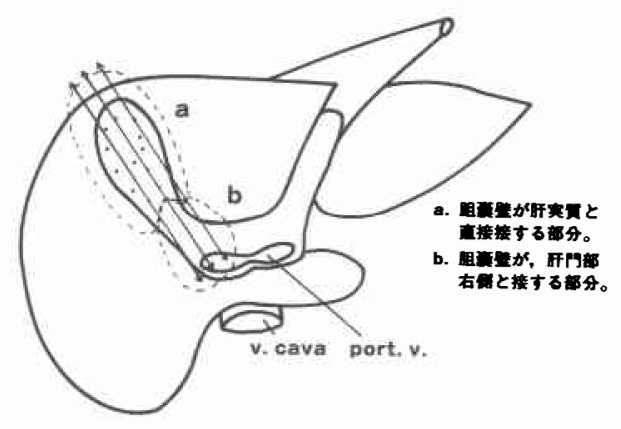

図 2 胆囊の付着形態

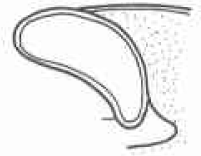

A

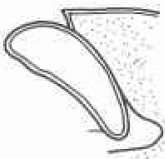

B

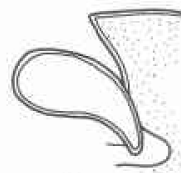

c
囊壁の中心を通り肝表面に垂直な方向の割面と，その 左右に $5 \mathrm{~mm}$ 扣いた平行面を各 1 枚，計 3 枚の割面を とって，肉眼拈よび光顕下に観察した(図 1 ). 成人の 9 体では, 全層胆摘術 ${ }^{10)}$ にしたがって胆囊を肝実質か ら䟝離していき，最下端部となる頸部と，訮内の肝十 二指腸間膜の連続である肝門部右側との結合織を求 め，その肉眼的位置関係を調へ，光顕下にもその連続 する部分を観察した。肝臓の区分についてはGlisson 系の脈管の分布をもとにした Couinaudの区域分類 ${ }^{11}$ をもちいた。

\section{結 果}

1. 胆震と肝葴の間の付着面の形態について

胆亭と肝藏との付着面積は個体差が大きいが，図 2 に示したようにおよそ A 型：胆衰窩が深く胆囊の獎 膜面がそのまま肝臟前縁に移行するむの, B 型：胆囊 壁の付着は肝臓の下面に始まり，この部分と肝蔵前縁 との距離は $2 \mathrm{~cm}$ 末満であるもの，C型：その距離が2 $\mathrm{cm}$ 以上あり, 胆亭と肝藏との付着が貧弱で胆囊窩も 浅いるの，の3 型に分類した。

各壁の頻度 $\mathrm{A} ： 8$ 例， $23.5 \%$

$$
\text { B : 25例, } 73.5 \%
$$$$
\text { C : } 1 \text { 例, } 3.0 \%
$$

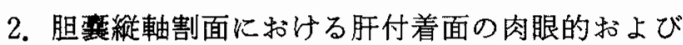
顕微鏡的所見

割面の肉眼的観察では, 胆囊壁は胆囊窩の肝実質と
困 5 肝床部付着上縁の顕微鏡像、 $\mathrm{A}$ 型：胆亳壁と肝 実質の間の境界線が不明瞭で両者が入り乱れてい る. $\times 10$, H.E.

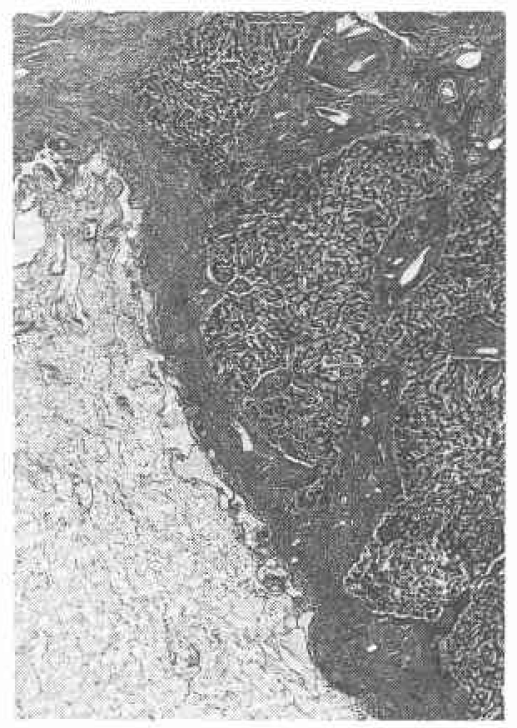

肝門部右側に連続性に広く付着している（図 1 の a, b). 胆囊底部の付着形態は前述のように個体差が大き いしかし体部では，付着幅には個体差が見られるも のの胆囊壁と肝実質間はいずれの型でも境界が明睹で あった，胆囊頸部のレベルでは胆哓漿膜下層が頸部粘 膜から遠ざかり，そのまま肝門右側の間膜組織に移行 する (b 部). 胆慗縱断面中心から $5 \mathrm{~mm}$ 左 (肝門側) の

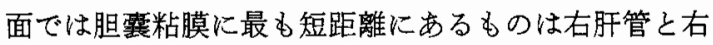
肝動脈であった（図３）、胆囊軸中心面です右肝動脈之 右肝管枝が，背側の門脈右枝よりも胆囊頸部粘膜に近 接して位置する。これらの脈管と胆囊頸部粘膜とはこ の断面でもっとも短距離にあった（図 4). 胆裹の中心 軸から $5 \mathrm{~mm}$ 右の断面では, 右肝管, 門脈右枝が多枝に 分岐する間膜組織の分䚳点が認められた，以上の所見 は成人20例の全例にみられた。

胆震縦断面の光顕での観察で, 図 2 の A 型では肝付 着上縁で胆囊漿膜下組織と肝実質小葉間組織が入りく んで境界が不明瞭であった(図 5)。しかし付着部上縁 以下では胆襄壁と肝実質は比較的明瞭に境界をもって いた，肝被膜の厚さ，扎よび胆囊肝境界部にみられる 結合織の厚さは, 成人例で $120 \sim 20 \mu$, 平均 $55 \mu, 120 \sim 20$ $\mu$, 平均 $59.4 \mu$ で, 6 歳までの小児では $30 \sim 10 \mu$, 平均 $19.2 \mu, 65 \sim 0 \mu$, 平均 $20.3 \mu$ であった. 新生児では 3 例 中 2 例に境界部結合織がみられなかった(図6)。境界 
図 6 胆衰と肝実質との間の境界，左図：成人例。明 瞭な境界膜（白矢印）が認められる。右図：新生児 例. 境界膜を認めない（黒矢印）。 $\times 5$, H.E.
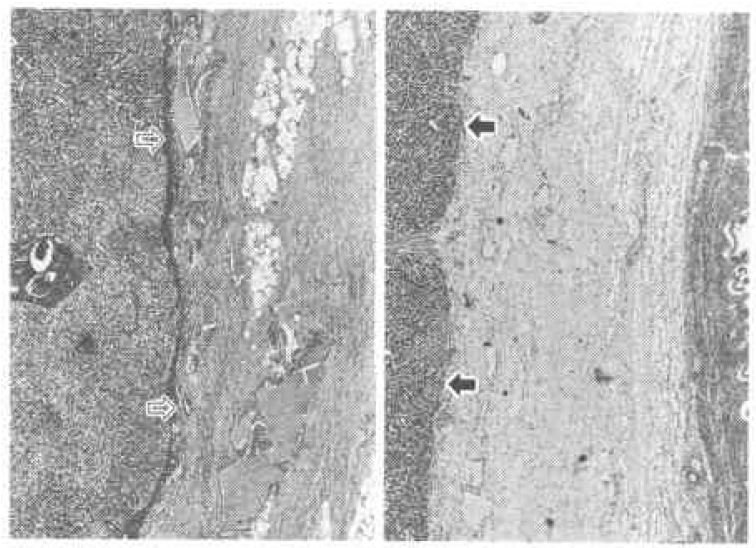

図 7 新生児の肝床部に㧍ける胆震と肝実質との境 界. 境界の胆竧側を走行するリンパ管群（矢印）を 示す. $\times 10$, H.E.

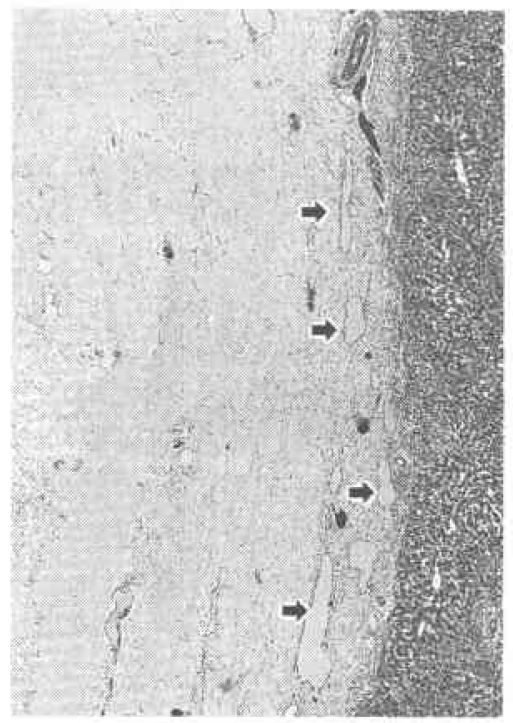

膜のすぐ胆震側には対象個体の全例に縦方向に走るリ ンパ管が見られた(図 7)。それらのリンパ管は頸部下 端の模式図 1 の $\mathrm{b}$ 部で胆衰粘膜から遠ざかり肝門に 向かって走行していた（図8）.

境界膜を有する全例で, 境界膜の肝臓側に細い肝末 梢の小葉間組織が多数接していて，そこでは境界膜が 中断し，肝の小葉間血管や小リンパ管が，陥入した胆 囊壁に連なる部分が見られた(図 9)。胆萇頸部と肝の
因 8 肝実質 (L) に沿って胆震から遠ざかるリンパ管 群 (矢印) を示す，新生巟例。 × 10, H.E.

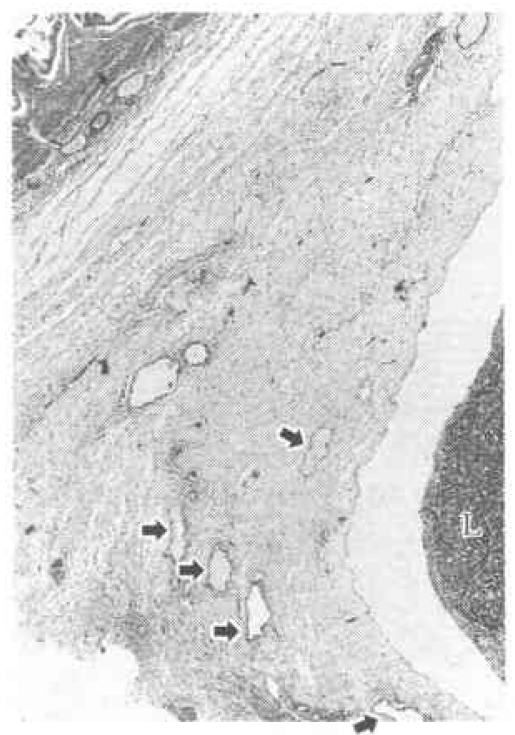

図 9 境界膜に侵入する小葉間組織。リンパ管の移行 るみとめられる.ここでは堺界膜が不明瞭. 成人 例. $\times 10$, H.E.

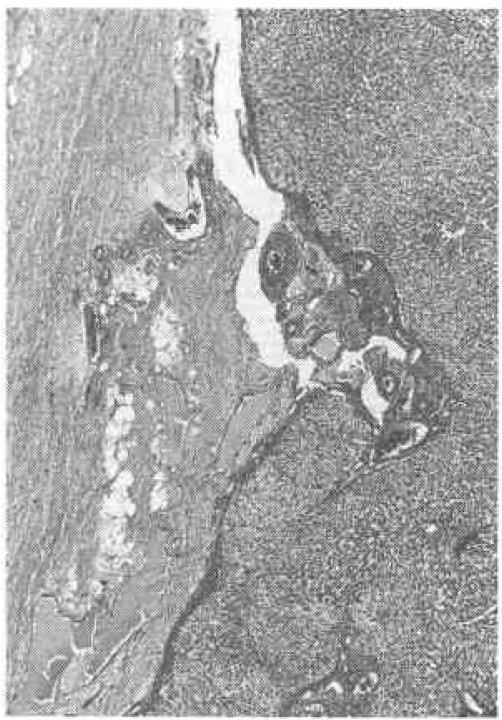

境界部では, 口径の大きいリンパ管や神経線維が胆管, 肝動脈周囲の間質中にとくに多く認められた（図10）。

3. 肝琵頸部下端と肝門部右側との連続性

成人肝の 9 例で胆呈を底部側から全層に㔀離してい くと, 第 1 項 $\mathrm{A}$ 型の付着緣で肝との刹離が困難な以外 
図 3 胆囊糈軸中心より $5 \mathrm{~mm}$ 内側の断面。右肝動脈 (R. HA)，総肝管 (CHD)，門脈 (PV) と胆囊管, 胆囊粘膜との位置関係を示す。

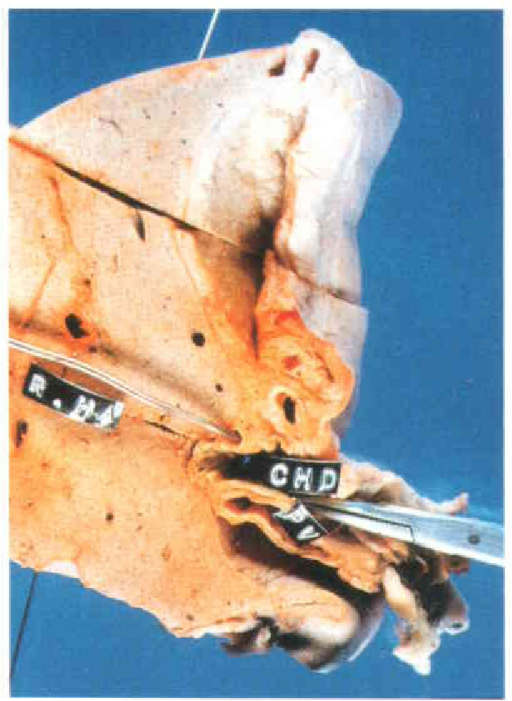

図 4 胆囊綎中心軸の断面。頸部筋層下に直接連なる 間質組織内に右肝動脈( R. HA)，右肝管，右門脈枝 (PV) があり，いずれも頸部粘膜からわずか $2 \mathrm{~cm}$ 以 内位置する。

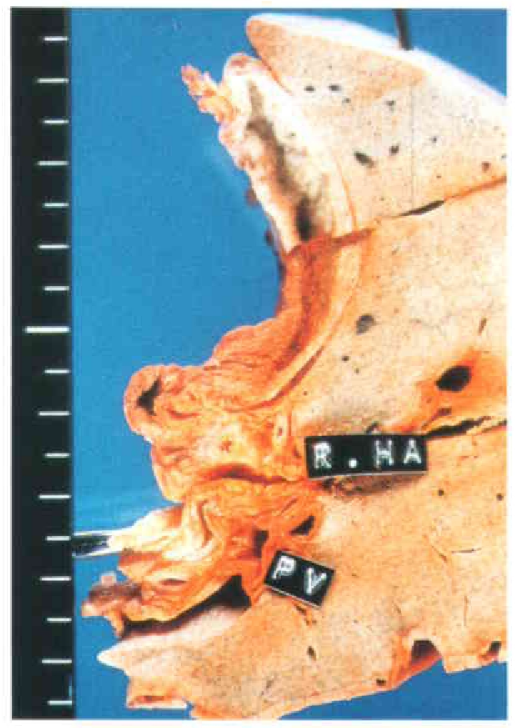

は，小数の索状の組織を切断しながら全例で比較的容 易に頸部の高さ京で剥離を進められた（図 1 の a 部）。 径 $1 \mathrm{~mm}$ 以上の索状結合織は多くて10本, 少ない例では 3 本程度であった。b部に至ると肝実質がしだいに遠
図10 胆囊頸部 (GB) 粘膜と肝門右側の間の組織像. 豊富なリンパ管 $(\rightarrow$ ) や神経線維 $(\Rightarrow)$ が胆管 $(\mathrm{B})$, 肝動脈 (A)の周囲に分布与る. 小児例. $\times 2.5$, H.E.

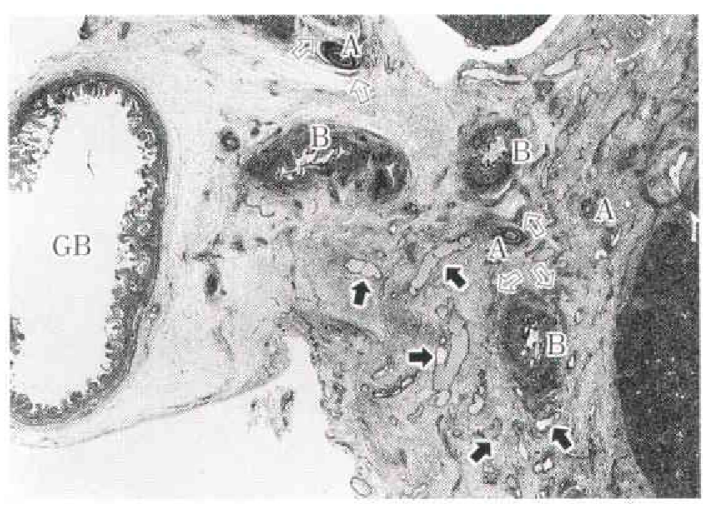

図11 全層胆摘に従って胆豊を剥離し胆囊頸部と肝門 部右側との索状のつながりを示す（矢印）。

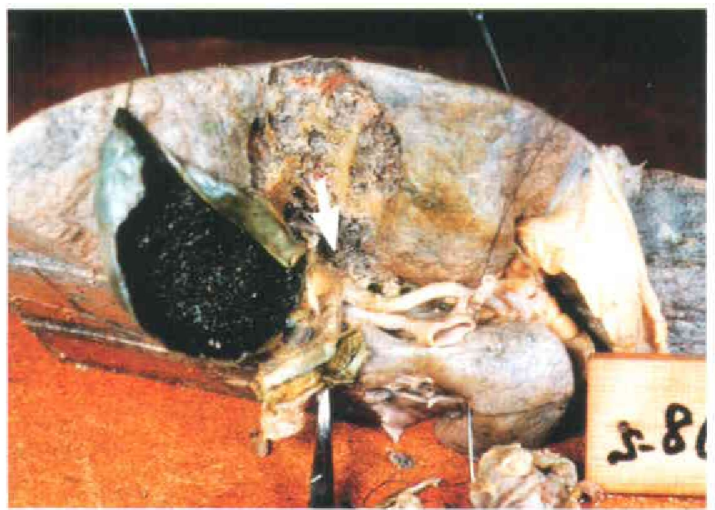

ざかり，9例のすべてで剥離面が肝門右側に深く入り こさ(図11)。脂肪織を除去していくと，肝門部右側で 胆囊壁と右肝動脈, 右肝管が索状の結合織によって連 続しているのが全例で観察された(図12). 光顕下に観 察するとその部分の索状構造の主体はリンパ管であ り,他に小数の神経線維や偽胆管を含んでいた(図13).

図14は胆囊付着部の肝実質を主な脈管を残して約2 $\mathrm{cm}$ 削り取ったものである。胆囊壁は右面では S50 Glisson 鞘枝之, 正面では中肝静脈枝と, 左面では S4 枝と近接していて, 胆囊体部壁の剥離中に切断を要し た索状の結合織がそれらの末梢枝であることを示し t.

\section{考察}

胆囊癌の予後がその深達度ともっとも関係が深いこ とはすでに多くの臨床家が指摘している ${ }^{1213)}$. しかし 
図12 図11矢印部の搪大。索状物の達する先は右肝動 脈执よび右肝管である。

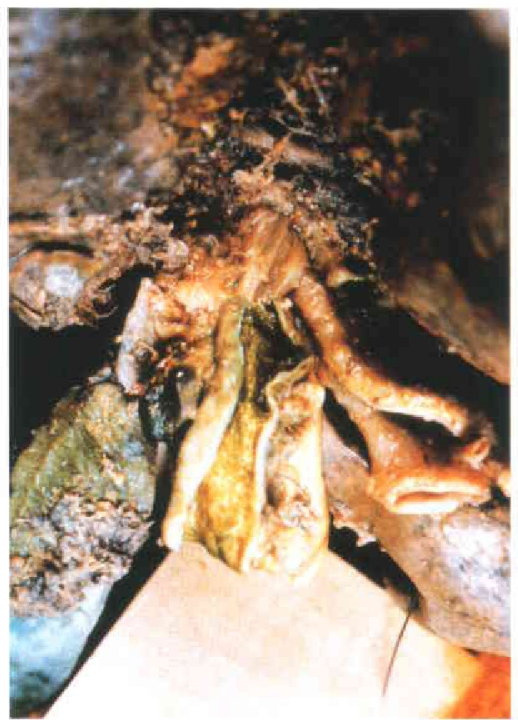

図13 図11矢印部の索状組織。綎断面。主にリンパ管 である. ×25, H.E.

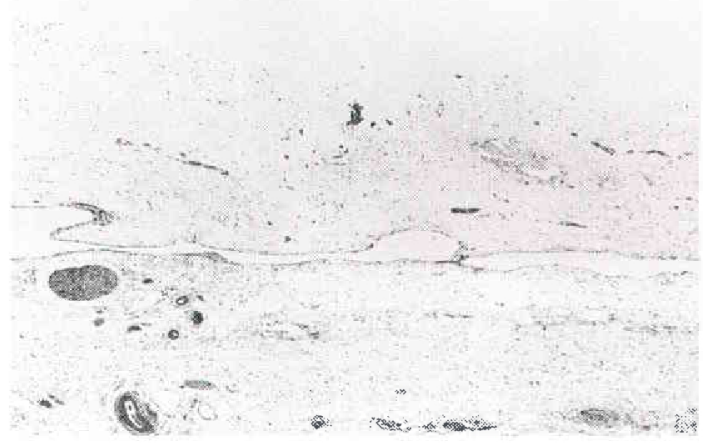

肝付着面では深達度の肉眼的定義と組織学的定義の間 にずれがあっで，漿膜側では ss 癌であっても，同様な 深達度のものが肝床部にあるといらだけで病期が相違 してしまい, 癌の本来の進展や予後を討論するには不 都合であるとわれわれは考劣てきた ${ }^{10)}$. た, 胆囊の付 着面が肝床部のみに注目されてきたさらいがあって, 頸部の壁から胆囊管にかけての間膜側への連続は, 肝 外に位置すると考学られがちであった。そこで胆囊の 付着形態を人の剖検肝を用いて前述の方法で検討を加 壳た結果，次の 2 点が明らかになった。第 1 に，胆囊 壁と肝実質との間には明らかな境界がないこと，第 2
図14 肝床面では右から S5区域枝が，左から S4区域 枝がそれぞれ胆囊壁周辺の肝実質内に小枝を出して いる。胆囊頸部と S5区域枝はしだいに接近して肝門 右側に集合する。
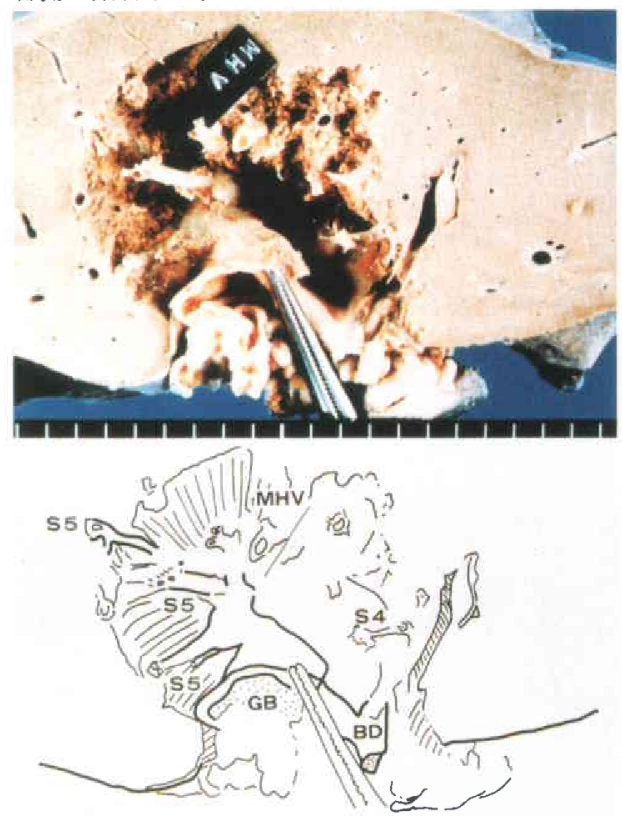

図15 胆囊肝床部に拈けるリンパの流れ、肝門部右側 への流れを強調した。

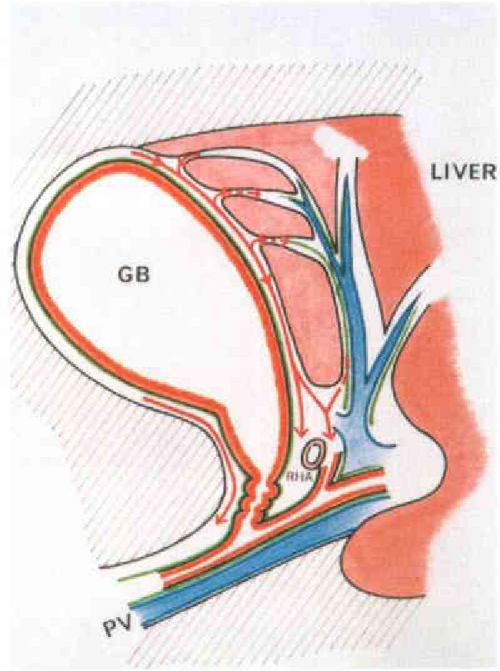

に，頸部の高さでは胆囊壁は，肝実質に包まれた肝門 部右側（右前枝，後枝分岐部をふくむ）から肝外に位 置する肝十二指腸間膜にかけて広く連続することであ る. 
肉眼的に癌腫が胆囊内に限局した stage の胆囊癌 は, 一部の隆起性の早期癌をのぞいて術前診断が困難 なことが少なくない14). またその深達度や局在の判定 は, 切除標本の肉眼的観察でもなかなか難しい。これ ら比較的早期の胆囊癌の進展に関して, 内田らは粘膜 上の癌が離開した筋層間を策状に浸潤し，漿膜下に至 るとリンパ管や組織間吵を側方へ速やかに進展するの ではないかと述べている ${ }^{15}$. その進展経路は, 胆囊壁内 のリンパ管の走行と一致するように見受けられる。

Winkenwerder はネコの胆囊りンパ管に色素を注入 し立体観察することによって，胆狦壁のリンパ管は Plexus subepithelialis, Plexus perimuscularis, Plexus subserosa の三層から成り，後 2 者は口径が大 きく小数の弁を持ら，またそれらは互いに交通して胆 囊所属リンパ節に注ぐが, 肝付着面では, 第 3 の Plexusを認めず. 胆囊と周辺肝との間にリンパの交通 はないとした ${ }^{16)}$. 森田 ${ }^{17}$, 田中 ${ }^{18)}$ は胆囊リンパ管網の微 細構造についてはWinkenwerderを支持したが, 肝付 着面でも弁を有する漿膜下リン八゚管綱を認め, 周辺肝 のリンパもこれに注ぐことを主張した。

われわれの検討です，胆鬴壁と肝実質との間には， 新生児では本来境界とよべるような組織は存在せず， 肝付着面では，肝実質に近接して口径の大きいリンパ 管が綎方向に走行して，しかもこのリンパ管は, 胆囊 壁が頸部の高さで肝門右側の間膜に連続するのに伴っ て背側に流れ，肝内で右側の間膜組織が多枝に枝別れ する手前付近で間膜内の右肝管，右肝動脈と絡みつく ことを観察した.

また持永らは，胆囊頸癌のリンパ流を遮断したイヌ の胆囊リンパ管に色素を注入し, 色素が肝床部の肝実 質内の小葉間に容易に逆流することを観察したとい $5^{19)}$.

以上のことから, 肝床部でも胆霟壁漿膜下リンパ管 が存在し, 胆囊浅層からのみならず，周辺肝からもり ンパを集合し, 肝門部や胆垔管周囲への流出経路と なっていると考兄られる(図15)。したがって胆囊癌で は肝床部筋層下（漿膜下層）を肝門部右側にむかうリ ンパの経路は, リンパが逆流する以前の段階での癌進 展の主要経路の一つであり, ss 胆囊癌では, 肝床面か らの肝実質内への経路より一層重視すべき部分である ことが推察される。 また上記のリンパの経路を逆流す る条件下では, 癌は早晚肝実質内や肝門に進展するこ とが予測される. 実際に, SS 胆鸾癌の術後では肝門部 への局所再発が占居部位を問わずしばしば見られ，と
クわけ頸部や胆露管を占居するものに多いようであ る $^{10220)}$. これらのリンパの流れに基づいて比較的早期 の胆震癌の合理的切除を，われわれは次のように考克 ている.

肉眼的所見で腫瘍が漿膜下層以下の深達度にとどす ると判定される場合では，1）肉眼所見で腫場が底部， 体部に限局していて,リンパの逆流の可能性の少ない， すなわち炎症所見が胆賈に軽度で肉眼的リンパ節転移 が認められない場合, 全層胆摘と肝外胆管切除を含む

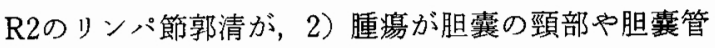
におよぶか, 胆囊管リンパ節に肉眼的転移を認めたり， 胆囊に強度の急性炎症がある場合は, 肝外の郭清と之 もに，S4，S5下区域切除に加光て可及的広範囲の右肝 動脈枝と右肝管枝の切除が必要である.

これに対し腫眴が漿膜に浸潤していたり，肝床部へ の浸潤がある場合や，肝十二指腸間膜浸潤を強く疑 症例では，たと兄腫瘍が胆震の近傍に限局していると の術中の所見でも，拡大肝右葉切除による右肝門全切 除が必要であろう。

そこで, 比較的早期の胆敕癌の予測される手術では, とりあ⿱す士全層胆摘を行い，術中の胆囊の外観や粘膜 上の所見から，上記の条件にしたがってその場で追加 切除を加えるべきであるといらのがわれわれの主張で ある。

\section{結語}

1. 成人では肝実質之胆囊との間に肝被膜とほぼ同 じ厚さの簿い結合織性の境界膜を有している.

2. 境界膜に沿った胆囊壁内には, 綐方向に並んだリ ンパ管が例外なく認められる。

3、境界膜の肝実質側には脈管を有する肝小葉間組 織が接している。境界膜はその部分で走行が不明瞭に なった。

4. 新生児では上記の境界膜が 3 例中 2 例で認めら れず, 境界膜は出生後の成長の過程で形成されると考 完らる。

5. 胆襄頸部の高さで, 肝床側の胆霬漿膜下組織(筋 層下の層）は前後枝分岐に近い肝門部右側の間膜に移 行する。

6. この移行部分には右肝管および右肝動脈周囲と 胆襄との間にリンパ管を主とする索状組織が例外なく 存在した。

7、以上のことから,肝床部を流れる胆囊の最外層の リンパの一部は, 右肝管と右肝動脈の周囲のリンパ管 に流れることが推測される. 
8. 胆囊頸部や胆霅管の漿膜下に侵入した胆震癌の 進展経路として6.のリンパ流を介する進展が考えら れ，それらに対しては肝門部右側の広い郭清が必要で ある。

本稿の要旨は第31回日本消化器外科学会で報告した。ご 指導を賜った浜松医科大学第 1 病理喜納 勇教授に深謝致 します。また研究に多大のご協力を頂いた志太総合病院病 理部，市沢末広氏はじめスタッフの皆様に感謝の意を捧げ ます。

\section{文献}

1）永川宅和, 浅野栄一, 宮崎逸夫汪か：胆婁癌の根治 手術について。消外 4:1117-1122, 1981

2）吉川達也, 羽生富士夫, 中村光司活 : 胆黄癌の治 療一胆襄癌拡大手術の意義. 胆之膆 4:1251 $-1261,1983$

3）森岡恭彦, 永井秀雄, 柏井昭良ほか：胆震癌の手 術. 胆と膵 $5: 479-488,1984$

4）渡辺栄二：超音波断層法による胆震癌診断に関す る臨床的研究一とくに早期診断能について一。 日 消外会誌 $16 ： 1684-1693,1983$

5) 日本胆道外科研究会編：外科, 病理, 胆道癌取り扱 い規約， 2 版。金原出版，東京， 1986

6）柿田 章, 上林正昭, 高橋 毅㴗胆衰癌の進展 様式. 肝胆膵 $10: 549-555,1985$

7）伊関文二, 牛山孝樹, 別府倫兄活加：胆变癌切除症 例の検討. 日消外会誌 $16: 607-612,1983$

8）田代征記, 持永瑞恵, 横山育三：胆婁癌の治療。と くに実験的胆囊癌から久た胆衰癌の治療方針。日 消外会誌 $9 ： 186-192 ， 1976$

9）永井秀雄, 黒田 慧, 森岡恭彦汪か：剖検例から反 た䏣襄癌の進展様式. 胆と膵 $4: 1227-1241$,
1983

10）脇 正志：比較的早期胆袈癌に関する病理学的研 究一全層胆摘術の意義に関連して一. 日外会誌 $89: 1040-1048,1988$

11) Couinaud $\mathrm{C}$ : Libes et segments hepatiques. Notes sur I' architecture anatomique et chirurgicale du foie. Press Med $62: 709-712,1954$

12) Nevin JE, Moran TJ, Kay S et al : Carcinoma of the gallbladder. Cancer 37:141-148, 1976

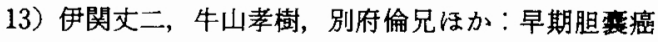
一臨床㧍よび病理学的検討一, 日消病会誌 79 ： $2112-2120,1982$

14）小山研二, 佐藤寿雄：胆襄癌早期例の特性とその 診断治療について。目消外会誌 $18 ： 879-882$, 1985

15）内田克之, 渡辺英伸, 味岡洋一ほか：胆霓癌の発 育. 進展, 肉眼型. 壁内発育様式. 癌の大きさから みて. 胃と腸 $22: 511-521 ， 1987$

16) Winkenwerder WL: A study of the lymphatics of the gallbladder of the cat. Johns Hopkins Hosp Bull 41:226-238, 1926

17）森田 聰：胆㶳リンバ液並びにリンバ管に就い て. 厇島医別刊 $9: 1-3,1956$

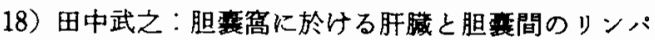
管交通, 並びに胆覆に於ける脈管外通液路に関す 了研究. 熊本医会誌 $33: 1392-1403 ， 1959$

19）持永瑞恵，田代征記，石原信彦注か：胆爱癌術後の 予後からみた治療法の検討一とくに組織学的深達 度とリンパ流を中心として一, 外科 $37: 952$ $-958,1975$

20）中山和道, 西村祥三, 吉田浩晃任加: 胆重癌根治手 術に拈ける盲点, 問題点. 日外会誌 $87: 1087$ $-1089,1986$ 